\title{
Damping constant, dielectric susceptibility, inverse relaxation time and the activation energy calculated as a function of temperature from the Raman frequency for the rhombohedral-tetragonal phase transition in $\mathrm{BaCeO}_{3}$
}

\author{
Ali KIRACI ${ }^{1}$, Hamit YURTSEVEN ${ }^{2, *}$ \\ ${ }^{I}$ Inter-Curricular Courses Department, Cankaya University, Ankara, Turkey \\ ${ }^{2}$ Department of Physics, Middle East Technical University, Ankara, Turkey \\ Geliș Tarihi (Recived Date): 20.08.2017 \\ Kabul Tarihi (Accepted Date): 07.11.2017
}

\begin{abstract}
Temperature dependences of the damping constant (half width at half maximum), dielectric susceptibility, inverse relaxation time and the activation energy using the $110 \mathrm{~cm}^{-1}$ and $125 \mathrm{~cm}^{-1}$ Raman modes are calculated in the ferroelectric phase $\left(T<T_{C}\right)$ of $\mathrm{BaCeO}_{3}$. Raman frequencies of these modes are related to the order parameter (spontaneous polarization) to calculate their damping constants using the pseudospinphonon coupled model and the energy fluctuation model for the orthorhombic-tetragonal transition in $\mathrm{BaCeO}_{3}\left(T_{C}=427 \mathrm{~K}\right)$. Our calculated values of the damping constant from both models are in good agreement with the observed data. The inverse relaxation time of the studied Raman modes is predicted using the calculated values of the damping constant from both models (PS and EF) and the values of the order parameter (squared). Dielectric susceptibility is also predicted through the observed frequencies of those Raman modes by using the Landau phenomenological theory. The values of the activation energy are also extracted from the damping constant as calculated from both models using the Raman modes studied in the ferroelectric phase of $\mathrm{BaCeO}_{3}$.
\end{abstract}

Keywords: Damping constant, dielectric susceptibility, inverse relaxation time, activation energy, $\mathrm{BaCeO}_{3}$.

$\mathrm{BaCeO} 3$ 'in rhombohedral-tetragonal faz geçişi için Raman frekansından sıcaklığın bir işlevi olarak hesaplanan sönüm sabiti, dielektrik duyarlılık, ters gevşeme zamanı ve aktivasyon enerjisi

$\ddot{O z e t}$

$\mathrm{BaCeO}_{3}$ kristalinin ferroelektrik fazında $\left(T<T_{C}\right), 110 \mathrm{~cm}^{-1}$ ve $125 \mathrm{~cm}^{-1}$ Raman kiplerini kullanarak sönüm katsayısı, dielektrik duyarlılık, ters gevşeme zamanı ve aktivasyon enerji değerleri sıcaklığa bağlı olarak hesaplanmıştır. $\mathrm{BaCeO}_{3}$ kristalinin ortorombik-tetragonal faz geçişinde $\left(T_{C}=427 \mathrm{~K}\right)$ sönüm katsayısı değerlerini hesaplamak için, sanki spin-fonon çiftlenim ve enerji dalgalanma modellerini kullanarak Raman frekans değerleri düzen parametresi (kendiliğinden polarizasyon) ile ilişkilendirilmiştir. Hesaplanan sönüm katsayı değerlerimiz, gözlemlenen verilerle iyi bir uyum içindedir. Çalışılan Raman kiplerinin ters gevşeme süresi, her iki modelden hesaplanan sönüm sabitinin değerleri ve kendiliğinden polarizasyon (karesi) değerleri kullanılarak öngörülmüştür. Dielektrik duyarlılıkta, Landau fenomenolojik teorisi kullanarak, gözlemlenen Raman frekansları aracılığıyla öngörülmüştür. $\mathrm{BaCeO}_{3}$ kristalinin ferroelektrik fazında,

Ali KIRACI, akiraci@ cankaya.edu.tr, http://orcid.org/0000-0003-4067-1004

*Hamit YURTSEVEN, hamit@metu.edu.tr, http://orcid.org/0000-0002-7745-6490 
çalışılan Raman kiplerini kullanarak her iki modelden hesaplanan sönüm sabitinden aktivasyon enerjisi değerleride çıkarlmııstır.

Anahtar sözcükler: Sönüm katsayısl, dielektrik duyarlllı, ters gevşeme süresi, aktivasyon enerji, $\mathrm{BaCeO}_{3}$.

\section{Introduction}

As a member of perovskite type ferroelectrics, barium cerate $\left(\mathrm{BaCeO}_{3}\right)$ is an attractive material due to its potential applications in solid state fuel cells [1]. Acceptor-doped $\mathrm{BaCeO}_{3}$ becomes a high temperature protonic conductor and it can be used as fuel elements also as hydrogen sensors [2]. Phase transitions in $\mathrm{BaCeO}_{3}$ have not been understood totally yet. Very contradictory results have been reported for the structural phase transition temperatures for $\mathrm{BaCeO}_{3}$ [3-5].

$\mathrm{BaCeO}_{3}$ is orthorhombic at room temperature with a space group $D_{2 h}(P b n m)$ with twenty atoms per unit cell [6]. As the temperature increases, structural phase transition from orthorhombic to tetragonal with a space group $D_{4 h}^{5}(P 4 / \mathrm{mbm})$ with ten atoms per unit cell at $427 \mathrm{~K}$ interpreted by Scherban et al. [3]. At higher temperatures, another structural phase transition was reported from tetragonal to cubic with a space group $O_{h}^{1}(P m 3 m)$ with 5 atoms per unit cell at $1112 \mathrm{~K}$ [3]. Various experimental methods including Raman spectroscopy [3,7], neutron diffraction [5,7], differential scanning calorimetry [8,9], x-ray powder diffraction [9] and dilatometry and electro-conductivity measurements [10] have been reported to understand the phase transition mechanism in $\mathrm{BaCeO}_{3}$. Also, some theoretical works have been carried out. Namely, Hartree- Fock and density functional theory approaches [11], quantum molecular dynamic study [12], calculation of the various thermodynamic properties from the density of state (DOS) of phonon [13] and the activation energy calculation [14] were reported in the literature.

In this study, we calculated the values of the dielectric susceptibility $\chi^{-1}$ using the $110 \mathrm{~cm}^{-1}$ and $125 \mathrm{~cm}^{-1}$ Raman modes from the Landau phenomenological theory through the observed frequencies [3] in the ferroelectric phase $\left(\mathrm{T}<\mathrm{T}_{\mathrm{C}}\right)$ of $\mathrm{BaCeO}_{3}\left(\mathrm{~T}_{\mathrm{C}}=427 \mathrm{~K}\right)$. We used the pseudospinphonon coupled (PS) model [15] and the energy fluctuation (EF) model [16] to calculate the damping constant $\Gamma$ (half width at half maximum) of those Raman modes studied for the orthorhombictetragonal transition in the ferroelectric phase of $\mathrm{BaCeO}_{3}$. This calculation was performed by associating the Raman [3] frequencies of the modes studied with the order parameter (spontaneous polarization) of polycrystalline $\mathrm{BaCeO}_{3}$. Additionally, we obtained the inverse relaxation time for the $110 \mathrm{~cm}^{-1}$ and $125 \mathrm{~cm}^{-1}$ Raman modes using the damping constant calculated from both models (PS and EF) and the observed frequency data [3] below the transition temperature $\left(\mathrm{T}_{\mathrm{C}}=427 \mathrm{~K}\right)$ of $\mathrm{BaCeO}_{3}$. Finally, the values of activation energy $U$ using the Raman frequencies deduced through the calculated damping constant values from the PS and $\mathrm{EF}$ models in the ferroelectric phase of $\mathrm{BaCeO}_{3}$.

Below, in section 2 we give our calculations and results. Discussion and conclusions are given in sections 3 and 4, respectively.

\section{Calculations and results}

The temperature dependence of the order parameter (spontaneous polarization) squared $\left(P^{2}\right)$ and the inverse dielectric susceptibility $\chi^{-1}$ using the frequencies of the $110 \mathrm{~cm}^{-1}$ and $125 \mathrm{~cm}^{-1}$ Raman modes in the ferroelectric phase $\left(\mathrm{T}<\mathrm{T}_{\mathrm{C}}\right)$ of $\mathrm{BaCeO}_{3}$ can be calculated by means of the Landau phenomenological theory for the second order rhombohedral-tetragonal phase transition in $\mathrm{BaCeO}_{3}$. The free energy $F$ for $\mathrm{BaCeO}_{3}$ can be expressed in terms of the order parameter $P$

$F=a_{0}+a_{2} P^{2}+a_{4} P^{4}+a_{6} P^{6}$

where $a_{2}=\alpha\left(T-T_{C}\right)$ with the constants of $\alpha, a_{0}$, $a_{4}$ and $a_{6} . T$ is the temperature while $T_{C}$ is the transition temperature. The free energy $F$ of the $\mathrm{BaCeO}_{3}$, which is thermodynamically stable, becomes minimum in the ferroelectric phase $(\mathrm{T}<$ $\mathrm{T}_{\mathrm{C}}$ ). From the minimization condition $d F / d P=0$, we found that

$\frac{d F}{d P}=P\left[2 a_{2}+4 a_{4} P^{2}+6 a_{6} P^{4}\right]=0$

This gives

$P=0$ and $2 a_{2}+4 a_{4} P^{2}+6 a_{6} P^{4}=0$

as the solutions of Eq. 2. $P=0$ (there is no ordering) corresponds to the paraelectric phase $\left(\mathrm{T}>\mathrm{T}_{\mathrm{C}}\right)$, and the solution for the second expression of Eq. 3 gives

$P^{2}=\frac{a_{4}}{3 a_{6}} \mp \frac{1}{3 a_{6}} \sqrt{a_{4}^{2}-3 a_{2} a_{6}}$

Under the conditions that $a_{4}<0$ and $a_{6}>0$, we found a positive $P$ solution of Eq. 4 that defines the ferroelectric phase $\left(\mathrm{T}<\mathrm{T}_{\mathrm{C}}\right)$. The square root term in Eq. 4 can be approximated by using the binomial 
expansion under the assumption that $a_{2} a_{6} / a_{4}^{2} \ll 1$, so that the Eq. 4 becomes

$P^{2}= \begin{cases}\frac{\alpha}{2 a_{4}}\left(T-T_{C}\right)-\frac{2 a_{4}}{3 a_{6}} & \text { negative root } \\ -\frac{\alpha}{2 a_{4}}\left(T-T_{C}\right) & \text { positive root }\end{cases}$
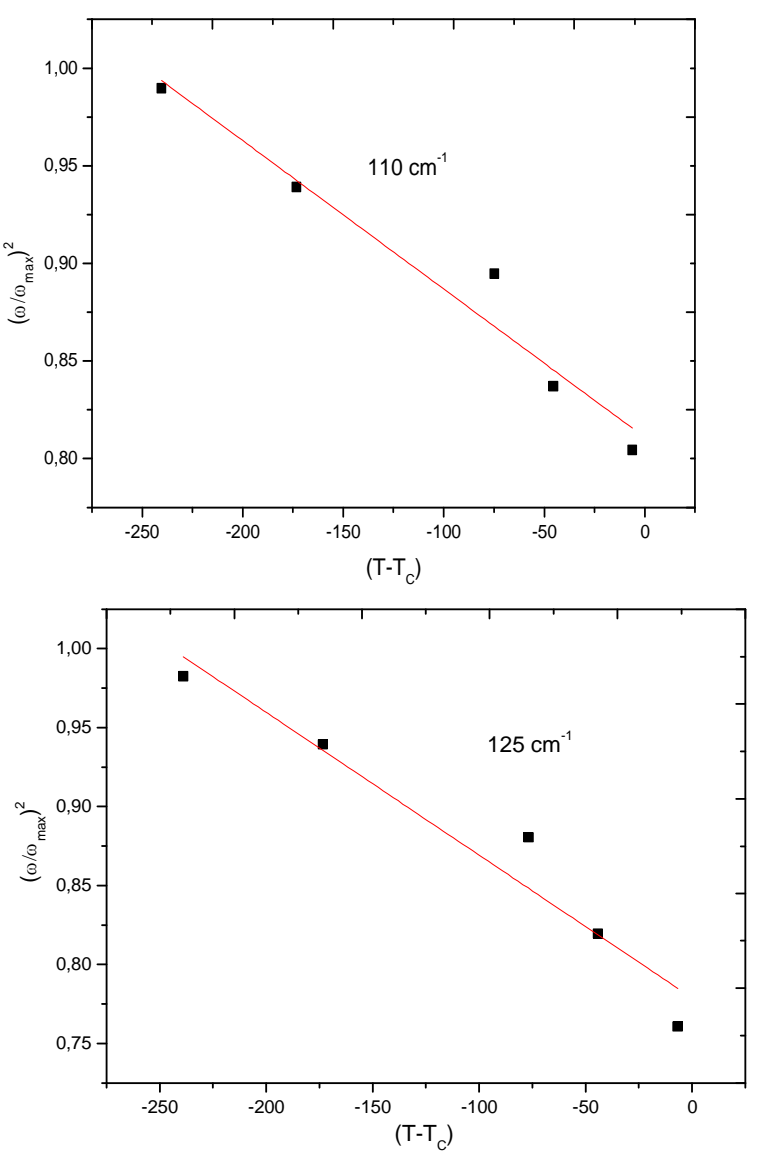

Figure 1. Temperature dependence of the normalized

$$
\text { (squared) frequency }\left(\frac{\omega}{\omega_{\max }}\right)^{2} \text {. }
$$

Table 1. Values of the $\omega_{\max }$ of Eq. 9, the parameters $\alpha$ and $a_{4}$ according to the negative root of Eq. (5).

\begin{tabular}{|c|c|c|c|c|c|}
\hline \multicolumn{3}{|c|}{ Raman modes } & $\omega_{\max }\left(\mathrm{cm}^{-1}\right)$ & $\alpha\left(10^{-3} 1 / K\right)$ & $-a_{4}$ \\
\hline \multicolumn{3}{|c|}{$110 \mathrm{~cm}^{-1}$} & 109.3 & 1.850 & 1.216 \\
\hline 125 & 127.9 & 2.111 & & 1.168 & \\
\hline
\end{tabular}

From the definition of the inverse dielectric susceptibility $\chi^{-1}$

$\chi^{-1}=\left(\partial^{2} \mathrm{~F} / \partial \mathrm{P}^{2}\right)$

its temperature dependence can be obtained as

$\chi^{-1}=2 \mathrm{a}_{2}+12 \mathrm{a}_{4} \mathrm{P}^{2}+30 \mathrm{a}_{6} \mathrm{P}^{4}$

By substitution of Eq. 5 into the Eq. 7, we found that

$\chi^{-1}=\frac{15}{2} \mathrm{a}_{6}\left(\frac{\alpha\left(\mathrm{T}-\mathrm{T}_{\mathrm{C}}\right)}{\mathrm{a}_{4}}\right)^{2}-12 \alpha\left(\mathrm{T}-\mathrm{T}_{\mathrm{C}}\right)+\frac{16}{3} \frac{\mathrm{a}_{4}^{2}}{\mathrm{a}_{6}}$
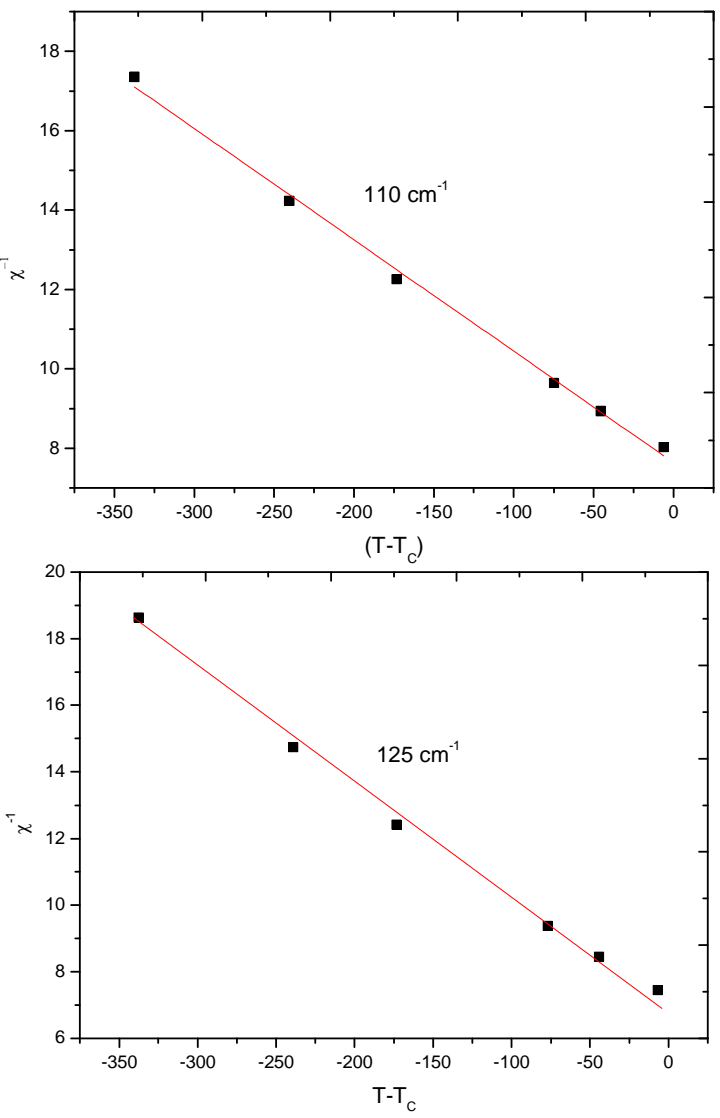

Figure 2. Temperature dependence of the inverse dielectric susceptibility $\chi^{-1}$.

The observed [3] Raman frequencies of these modes decrease with increasing temperature as the order parameter which is predicted from the mean field theory. Since the order parameter $P$ can take any value between 0 and 1, we associated the observed [3] frequencies $(\omega)$ of the $110 \mathrm{~cm}^{-1}$ and $125 \mathrm{~cm}^{-1}$ Raman modes with the order parameter $P$ according to,

$\frac{\omega}{\omega_{\max }} \propto \mathrm{P}$

where $\omega_{\max }$ is the maximum value of the Raman frequency. We analyzed the normalized observed frequencies $\left(\frac{\omega}{\omega_{\max }}\right)^{2}$ of the $110 \mathrm{~cm}^{-1}$ and $125 \mathrm{~cm}^{-1}$ Raman modes as a function $T-T_{C}$, which are plotted in Fig. 1 with the fitting parameters $\alpha$ and $a_{4}$ were extracted through the negative root of Eq. 5 . Those fitting parameters are given in Table 1 in the temperature interval indicated. The coefficient $a_{6}$ was taken unity $\left(a_{6}=1\right)$. This is due to the fact that our solution of the spontaneous polarization $P$ (Eq. $5)$ was based on the approximation $\left(a_{2} a_{6} / a_{4}^{2} \ll 1\right)$ in order to simplify the solution by regarding very small values of $\alpha$ and almost -1 value of $a_{4}$ for the Raman modes (Table 1 ). We were unable to determine the fitting parameters $\alpha$ and $a_{4}$ separately by using the positive root of Eq. 5 since it just 
allowed us to find the ratio of $\frac{\alpha}{a_{4}}$. With these parameters (Table 1), we predicted the inverse dielectric susceptibility $\chi^{-1}$ using the $110 \mathrm{~cm}^{-1}$ and $125 \mathrm{~cm}^{-1}$ Raman modes in the ferroelectric phase of $\mathrm{BaCeO}_{3}$ by Eq. 8 which are plotted in Fig. 2 .

The PS model [15] and the EF model [16] can be used to calculate the damping constant (half width at half maximum) of the Raman modes studied for $\mathrm{BaCeO}_{3}$. The temperature dependence of the damping constant is considered according to the PS model

$\Gamma_{\mathrm{SP}}=\check{\Gamma}_{0}+\hat{A}\left(1-\mathrm{P}^{2}\right) \ln \left[\frac{\mathrm{T}_{\mathrm{C}}}{\mathrm{T}-\mathrm{T}_{\mathrm{C}}\left(1-\mathrm{P}^{2}\right)}\right]$

and using the EF model [16] as

$\Gamma_{\mathrm{SP}}=\Gamma_{0}+\mathrm{A}\left[\frac{\mathrm{T}\left(1-\mathrm{P}^{2}\right)}{\mathrm{T}-\mathrm{T}_{\mathrm{C}}\left(1-\mathrm{P}^{2}\right)}\right]^{1 / 2}$

In Eqs. 10 and 11, $\Gamma_{0}$ and $\Gamma_{0}$ are the background damping constants and $A, A$ are the amplitudes. We used Eq. 9 to calculate the temperature dependence of the damping constant of the Raman modes from PS and EF models in Eqs. 10 and 11, respectively. We fitted Eqs. 10 and 11 to the observed damping constant data [3] to get the fitting parameters $\left(\Gamma_{0}, \Gamma_{0}\right.$, $A$ and $A$ ), as given in Table 2 for the indicated temperature ranges. Our calculated values of the damping constant from both models (PS and EF) for various temperatures of the $110 \mathrm{~cm}^{-1}$ and $125 \mathrm{~cm}^{-1}$ Raman modes in the ferroelectric phase of $\mathrm{BaCeO}_{3}$ were given in Fig. 3. Observed data [3] were also given in this figure.

We also predicted values of the inverse relaxation time $\tau^{-1}$ of the Raman modes according to

$\tau^{-1}=\frac{P^{2}}{\Gamma}$

Our predicted values of the inverse relaxation time $\tau^{-1}$ which were calculated through the $\Gamma$ values from both models (Eqs. 10 and 11) and $P^{2}$ through Eq. 9 are plotted in Fig. 4 as a function of the $T-T_{C}$ in the ferroelectric phase of $\mathrm{BaCeO}_{3}$.

The values of the activation energy $U$ can also be evaluated using the total linewidth $\Gamma$ (damping constant) which was given previously [17-19],

$\Gamma \cong \Gamma_{\mathrm{vib}}+\operatorname{Cexp}\left(-\mathrm{U} / \mathrm{k}_{\mathrm{B}} \mathrm{T}\right)$

where $\Gamma_{v i b}$ is the vibrational relaxation, $k_{B}$ is the Boltzmann constant and $C$ is a constant. The orientational motion of the $\mathrm{CeO}_{6}$ octahedra in $\mathrm{BaCeO}_{3}$ causes decrease in the linewidth of the highly energetic vibrational modes (vibrons) at temperatures $\mathrm{T}<\mathrm{T}_{\mathrm{C}}$. Above the transition temperature $\mathrm{T}_{\mathrm{C}}$ of $\mathrm{BaCeO}_{3}$, a broadening of the linewidth occurs. For the $110 \mathrm{~cm}^{-1}$ and $125 \mathrm{~cm}^{-1}$ vibration modes with lower energies that we study here, a variation of the damping constant with temperature is relatively small when compared with vibrations in the vicinity of the transition temperature $\mathrm{T}_{\mathrm{C}}$. So, the activation energy $U$ can be expressed as

$\ln \Gamma_{\mathrm{SP}} \cong \ln \mathrm{C}-\mathrm{U} / \mathrm{k}_{\mathrm{B}} \mathrm{T}$
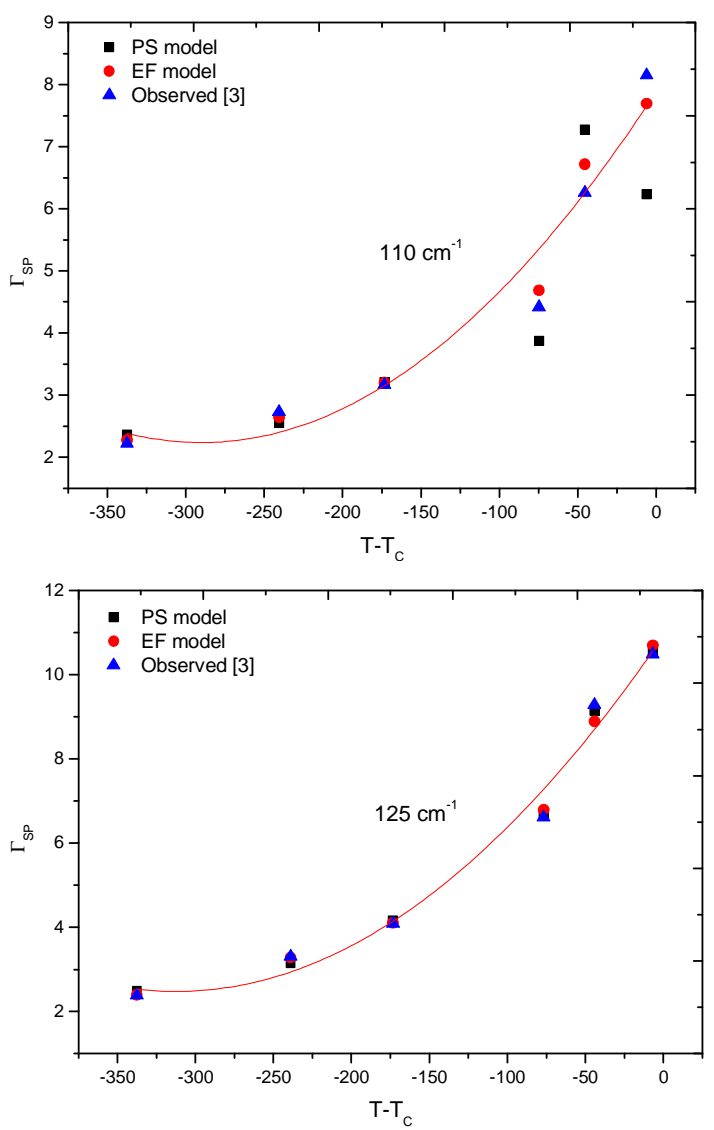

Figure 3. Damping constant $\Gamma_{S P}$ (half width at half maximum) as a function of $T-T_{C}$. Experimental data [3] are also given.

Table 2. Values of the fitted parameters for the damping constant $\Gamma_{S P}$ of the Raman modes $\left(110 \mathrm{~cm}^{-1}\right.$ and $\left.125 \mathrm{~cm}^{-1}\right)$ using the experimental data [3] according to the PS model (Eq. 10) and the EF model (Eq. 11).

\begin{tabular}{cccccc}
\hline $\begin{array}{c}\text { Raman } \\
\text { modes }\end{array}$ & $\dot{\Gamma}_{0}$ & $\Gamma_{0}$ & $\dot{A}$ & $A$ & $\begin{array}{c}\text { Temperature } \\
\text { Interval }(\mathrm{K})\end{array}$ \\
\hline $110 \mathrm{~cm}^{-1}$ & 2.36 & 22.2 & 2.28 & 3.56 & $\begin{array}{c}-337.4<\left(\mathrm{T}-\mathrm{T}_{\mathrm{C}}\right)<- \\
173.2\end{array}$ \\
& - & 207.10 & - & 20.50 & $\begin{array}{c}-173.2<\left(\mathrm{T}-\mathrm{T}_{\mathrm{C}}\right)<- \\
6.1\end{array}$ \\
& 3.31 & & 2.44 & & $\begin{array}{c} \\
125 \mathrm{~cm}^{-1}\end{array}$ \\
& 2.48 & 43.82 & 2.40 & 6.57 & $\begin{array}{c}-337.6<\left(\mathrm{T}-\mathrm{T}_{\mathrm{C}}\right)<- \\
173.4\end{array}$ \\
& 0.69 & 140.53 & - & 20.78 & $-76.1<\left(\mathrm{T}-\mathrm{T}_{\mathrm{C}}\right)<-6.7$ \\
& & & 0.99 & & \\
\hline
\end{tabular}


Table 3. Values of the activation energy $U$ extracted from Eq. (14) for the Raman modes indicated by using the PS and EF models. $k_{B} T_{C}$ value of $\mathrm{BaCeO}_{3}$ is $37 \mathrm{meV}$.

\begin{tabular}{llllll}
\hline $\begin{array}{l}\text { Raman } \\
\text { modes }\end{array}$ & $\begin{array}{l}U(\mathrm{meV}) \\
\text { PS }\end{array}$ & $\begin{array}{r}C \\
\mathrm{PS}\end{array}$ & $\begin{array}{l}U(\mathrm{meV}) \\
\mathrm{EF}\end{array}$ & $\begin{array}{c}C \\
\mathrm{EF}\end{array}$ & $\begin{array}{l}\text { Temperature } \\
\text { Interval }(\mathrm{K})\end{array}$ \\
\hline $110 \mathrm{~cm}^{-1}$ & 27 & 13 & 30 & 15 & $186<\mathrm{T}<420$ \\
& 40 & 19 & 47 & 26 & $253<\mathrm{T}<420$ \\
& 86 & 76 & 91 & 99 & $352<\mathrm{T}<420$ \\
$125 \mathrm{~cm}^{-1}$ & 35 & 24 & 34 & 24 & $188<\mathrm{T}<420$ \\
& 50 & 40 & 51 & 41 & $253<\mathrm{T}<420$ \\
& 84 & 111 & 83 & 106 & $350<\mathrm{T}<420$ \\
\hline
\end{tabular}

We extracted the activation energy $U$ of the 110 $\mathrm{cm}^{-1}$ and $125 \mathrm{~cm}^{-1}$ Raman modes through Eq. 13 by using our calculated values of $\Gamma$ from both models (Eqs. 10 and 11) below the transition temperature $\left(\mathrm{T}_{\mathrm{C}}=427 \mathrm{~K}\right)$ of $\mathrm{BaCeO}_{3}$. Table 3 gives our calculated values of the activation energy $U$ and the constant $C$ in the temperature intervals indicated.

\section{Discussion}

We predicted the temperature dependence of the inverse dielectric susceptibility $\chi^{-1}$ of the $110 \mathrm{~cm}^{-1}$ and $125 \mathrm{~cm}^{-1}$ Raman modes of $\mathrm{BaCeO}_{3}$ using the Landau theory for the orthorhombic-tetragonal transition below the transition temperature $\mathrm{T}_{\mathrm{C}}\left(\mathrm{T}_{\mathrm{C}}=\right.$ $427 \mathrm{~K}$ ). For this prediction of the $\chi^{-1}$ (Eq. 8), we associated the observed Raman frequencies $\omega$ [3] with the order parameter $P$ according to Eq. 9 and from a fitting procedure of the normalized observed frequency $\left(\frac{\omega}{\omega_{\max }}\right)^{2}$ with the reduced temperature $T-T_{C}$ (Fig. 1), we deduced the values of the $\alpha$ and $a_{4}$ (Table 1).

Using the relation between $\omega$ and $P$ (Eq. 9), we calculated the damping constant (half width at half maximum) of the $110 \mathrm{~cm}^{-1}$ and $125 \mathrm{~cm}^{-1}$ Raman modes in the ferroelectric phase of $\mathrm{BaCeO}_{3}$ through the PS and the EF models. As the temperature increases toward the transition temperature, the damping constant values calculated from the PS and EF models increase also. The pseudospin-phonon coupling, that is considered for both PS and EF models studied here, leads to the pseudospin waves [20]. This is interacted with all phonons in the crystal that causes to shortened their lifetimes and broadened the damping constant (damping constant is inversely proportional with the spin lattice relaxation time). In the ferroelectric phase $\left(\mathrm{T}<\mathrm{T}_{\mathrm{C}}\right)$ of $\mathrm{BaCeO}_{3}$ due to the reorientation of the $\mathrm{CeO}_{6}$ octahedra coupled with the phonons (pseudospinphonon coupling) according to the PS and EF models, the Raman intensities become intensed so that the damping constant (linewidth) decreases. As the temperature increased above $\mathrm{T}_{\mathrm{C}}$, the pseudospinphonon coupling weakened which causes the Raman intensities broaden. This leads to the broadening in the linewidths or the increasing in the damping constant in $\mathrm{BaCeO}_{3}$. Particularly, for the $110 \mathrm{~cm}^{-1}$ Raman mode in the temperature interval of $89.6<\mathrm{T}(\mathrm{K})<253.8$ and for the $125 \mathrm{~cm}^{-1}$ Raman mode in the temperature interval of $89.4<\mathrm{T}(\mathrm{K})<253.6$ the damping constant increased almost linearly while between the temperature interval of $352.2<\mathrm{T}(\mathrm{K})<420.9$ of the $110 \mathrm{~cm}^{-1}$ Raman mode and between the temperature interval of $350.3<\mathrm{T}(\mathrm{K})<420.3$ of the $125 \mathrm{~cm}^{-1}$ Raman mode, the damping constant increased very rapidly (Fig. 3). There was no anomalous behavior for the damping constant calculated from both models (PS and EF) near the transition temperature which indicates a second order phase transition as pointed out previously [3]. As an extension of this work, we predicted the temperature dependence of the inverse relaxation time $\tau^{-1}$ of the Raman modes studied through Eq. (12) in the ferroelectric phase of $\mathrm{BaCeO}_{3}$.
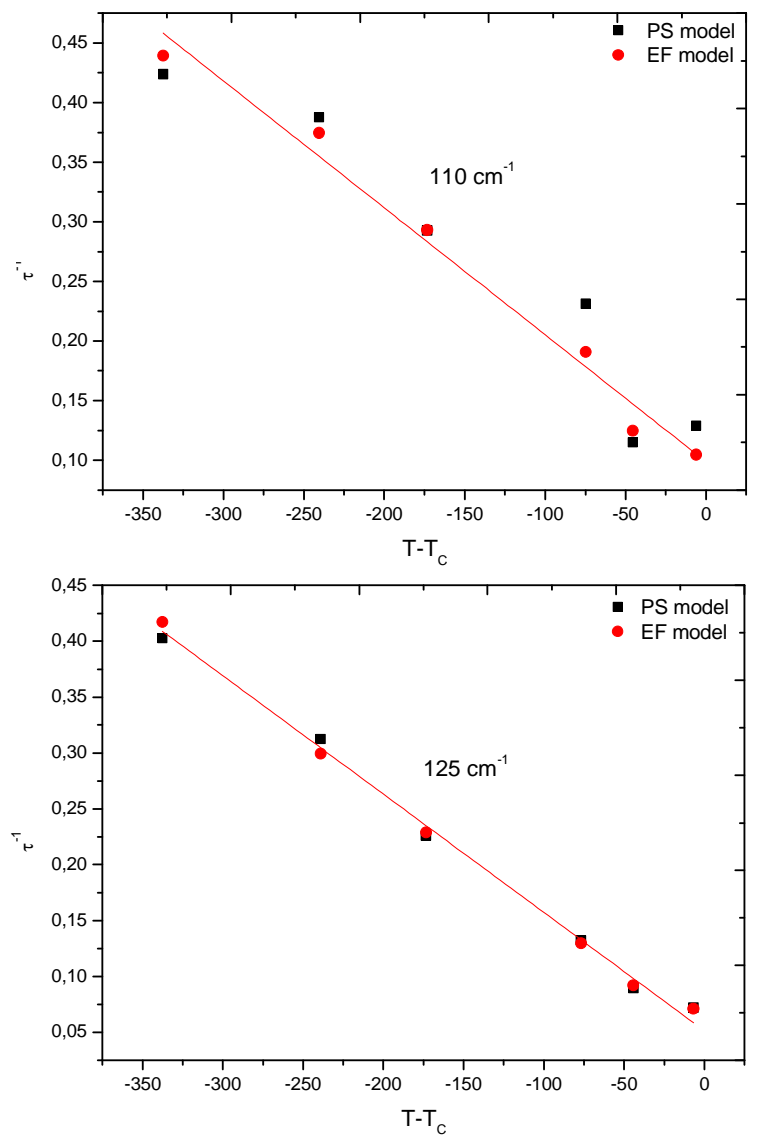

Figure 4. Inverse relaxation time $\tau^{-1}$ of the Raman modes $\left(110 \mathrm{~cm}^{-1}\right.$ and $\left.125 \mathrm{~cm}^{-1}\right)$ as a function of the $T-T_{C}$.

We checked several references in the literature to compare our predictions of the inverse susceptibility $\left(\chi^{-1}\right)$ and inverse relaxation time $\left(\tau^{-1}\right)$ in the ferroelectric phase close to $\mathrm{T}_{\mathrm{C}}$ for $\mathrm{BaCeO}_{3}$. Unfortunately, due to the lack of experimental and theoretical data related with $\chi^{-1}$ and $\tau^{-1}$, we could 
not make any comparison. Since our calculated values of $\chi^{-1}$ and $\tau^{-1}$ were based on the experimental data for the Raman frequencies of the 110 and $125 \mathrm{~cm}^{-1}$ modes [3], we expect that $\chi^{-1} \mathrm{vs}$.

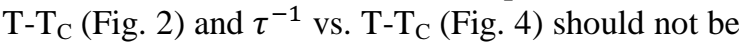
away from the experimental measurements.

Finally, we extracted the values of the activation energy $U$ using the damping constants of the Raman modes of $\mathrm{BaCeO}_{3}$ from both PS and EF models for various temperatures (Table 3). This calculation of the activation energy $U$ was performed in terms of the Arrhenius plot (ln $\Gamma v s .1 / T)$ according to Eq. 14 . The slope of this plot gave us the activation energy $U$ and the intercept value $C$ (Table 3 ). We compared our calculated values of the activation energy with the $k_{B} T_{C}$ value $(37 \mathrm{meV})$. The extracted values of the activation energy increased as the temperature intervals were closer to the transition temperature $\mathrm{T}_{\mathrm{C}}=427 \mathrm{~K}$. In particular, for the temperature interval of $352 \mathrm{~K}-420 \mathrm{~K}$ due to the $110 \mathrm{~cm}^{-1}$ mode and for the temperature interval of $350 \mathrm{~K}-420 \mathrm{~K}$ using the $125 \mathrm{~cm}^{-1}$ mode, our calculated values of the activation energy were almost three times larger than the $k_{B} T_{C}$ value (Table 3). This shows that the reasonable $U$ values extracted from the damping constants of the 110 and $125 \mathrm{~cm}^{-1}$ Raman modes, can be attained within a wider temperature range of $186<\mathrm{T}(\mathrm{K})<420$ using both models (PS and $\mathrm{EF}$ ) in $\mathrm{BaCeO}_{3}$.

\section{References}

[1] Iwahara, H., High temperature proton conducting oxides and their applications to solid electrolyte fuel cells and steam electrolyzer for hydrogen production, Solid State Ionics, 28-30, 573- 578, (1988).

[2] Scherban, T., Lee, W.K. and Nowick, A.S., Bulk protonic conduction in $\mathrm{Yb}$-doped $\mathrm{SrCeO}_{3}$ and $\mathrm{BaCeO}_{3}$, Solid State Ionics, 2830, 585-588, (1988).

[3] Scherban, T., Villeneuve, R., Abello, L. and Lucazeau, G., Raman-scattering study of phase-transitions in undoped and rare-earth ion-doped $\mathrm{BaCaO}_{3}$ and $\mathrm{SrCeO}_{3}$, Journal of Raman Spectroscopy, 24, 805-814, (1993).

[4] Loridant, S., Abello, L., Siebert, E. and Lucazeau, G., Correlations between structural and electrical properties of $\mathrm{BaCeO}_{3}$ studied by coupled in-situ Raman scattering and impedance spectroscopy, Solid State Ionics, 78, 249-258 (1995).

[5] Knight, K.S., Structural phase transitions in $\mathrm{BaCeO}_{3}$, Solid State Ionics, 74, 109-117, (1994).

[6] Jacobsen, A.J., Tofield, B.C. and. Fender, B.E.F, The structures of $\mathrm{BaCeO}_{3}, \mathrm{BaPrO}_{3}$ and $\mathrm{BaTbO}_{3}$ by neutron diffraction: lattice
In our earlier works, we used the PS and EF models to explain the phase transition mechanism of $\mathrm{BaTiO}_{3}$ [21], $\mathrm{PbZr}_{1-\mathrm{x}} \mathrm{Ti}_{\mathrm{x}} \mathrm{O}_{3}$ [22], $\mathrm{SrZrO}_{3}$ [23] and $\mathrm{LiNbO}_{3}$ [24] in the vicinity of the phase transition temperatures. These two models provide an advantage to analyze the experimental data for the ferroelectric materials due to their simplicity.

\section{Conclusions}

The damping constant calculated from the PS and the EF models was fitted to the observed data using the Raman frequencies of the lattice modes (110 and $\left.125 \mathrm{~cm}^{-1}\right)$ in the ferroelectric phase of $\mathrm{BaCeO}_{3}$. The damping constant calculated from the EF model agreed better than that calculated from the PS model when it was compared with the experimental data.

The inverse dielectric susceptibility and the inverse relaxation time were predicted as a function of temperature using the observed Raman frequencies $\left(110 \mathrm{~cm}^{-1}\right.$ and $\left.125 \mathrm{~cm}^{-1}\right)$ by the Landau theory in the ferroelectric phase of $\mathrm{BaCeO}_{3}$. Both quantities decreased almost linearly as the temperature increased toward the transition temperature $T_{C}$.

The Values of the activation energy using the Raman modes of $\mathrm{BaCeO}_{3}$ were also extracted, which are much greater than the $k_{B} T_{C}$ value of this system.

[7] Genet, F., Loridant S., Ritter C. and Lucazeau G., Phase transitions in $\mathrm{BaCeO}_{3}$ : neutron diffraction and Raman studies, Journal of Physics and Chemistry of Solids, 60, 20092021, (1999).

[8] Egorov, V.M., Baikov, Yu.M., Kartenko, N.F., Melekh, B.T. and Filin, Yu.N., Calorimetric study of phase transitions in the perovskite $\mathrm{BaCeO}_{3}$, Physics of Solid State, 11, 1911-1914, (1998).

[9] Melekh, B.T., Egorov, V.M., Baikov, Y.M., Kartenko, N.F., Filin, Y.N., Kompan, M.F., Venus, G.B. and Kulik V.B., Structure, phase transitions and optical properties of pure and rare earth doped $\mathrm{BaCeO}_{3}, \mathrm{SrCeO}_{3}$ prepared by inductive melting, Solid State Ionics, 97, 465-470 (1997).

[10] Kuzmin, A.V., Gorelov, V.P., Melekh, B.T., Glerup, M. and Poulsen, F.W. Phase transitions in undoped $\mathrm{BaCeO}_{3}$, Solid State Ionics, 162-163,13-22 (2003).

[11] Cammarata, A., Martorana, A. and Duca, D., Cation environment of $\mathrm{BaCeO}_{3}$-based protonic conductors: A computational study, 
The Journal of Physical Chemisty, A 113, 6381-6390 (2009).

[12] Münch, W., Seifert, G., Kreuer, K.D. and Maier, J., A quantum molecular dynamics study of proton conduction phenomena in $\mathrm{BaCeO}_{3}$, Solid State Ionics, 86-88, 647-652 (1996).

[13] Aycıbın, M., Erdinc, B. and Akkus, H., Electronic Structure and Lattice Dynamics of $\mathrm{BaCeO}_{3}$ compound in cubic phase, Journal of Electronic Materials, 43, 4301-4307 (2014).

[14] Mitsui, A., Miyayaman M.mand Yongagida H., Evaluation of the activation energy for proton conduction in perovskite-type oxides, Solid State Ionics, 22, 213-217 (1987).

[15] Lahajnar, G., Blinc, R. and Zumer, S., Proton spin-lattice relaxation by critical polarization fluctuations in $\mathrm{KH}_{2} \mathrm{PO}_{4}$, Physics of Condensed Matter, 18, 301-316 (1974).

[16] Schaack, G. and Winterfeldt, V., Temperature behaviour of optical phonons near Tc in triglycine sulphate and triglycine selenite, Ferroelectrics, 15, 35-41, (1977).

[17] Rakov, A.V., Brownian rotational movement of molecules of substances in the condensed state examined by Raman and infrared absorption, Optics and Spectroscopy, 7, 128-134, (1959).

[18] Bartoli, F.J. and Litovitz, T.A., Raman Scattering: Orientational Motions in Liquids,
The Journal of Chemical Physics, 56, 413425 (1972).

[19] Fahim, M.A., A detailed IR study of the order-disorder phase transition of $\mathrm{NaNO}_{2}$, Thermochimica Acta, 363, 121-127, (2000).

[20] Blinc, R. and Zeks, B., Dynamics of orderdisorder-type ferroelectrics and antiferroelectrics, Advances in Physics. 21, 693757 (1972).

[21] Kiraci, A. and Yurtseven, H., Calculation of the damping constant and the relaxation time for the soft-optic and acoustic mode in hexagonal barium titanate. Ferroelectrics,437, 137-148, (2012).

[22] Yurtseven, H. and Kiraci, A, Damping constant (linewidth) and the relaxation time of the Brillouin LA mode for the ferroelectric-paraelectric transition in $\mathrm{PbZr}_{1-\mathrm{x}} \mathrm{Ti}_{\mathrm{x}} \mathrm{O}_{3}$, IEEE Transactions on Ultrasonics, Ferroelectrics, and Frequency Control, 63, 1647-1655 (2016).

[23] Kiraci, A. and Yurtseven, H., Temperature dependence of the damping constant and the relaxation time close to the tetragonal-cubic phase transition in $\mathrm{SrZrO}_{3}$, Journal of Molecular Structure, 1128, 51-56, (2017).

[24] Kiraci, A. and Yurtseven, H., Temperature dependence of the polarization, dielectric constant, damping constant and the relaxation time close to the ferroelectric-paraelectric phase transition in $\mathrm{LiNbO}_{3}$, Optik, 132, 183191, (2017). 